\title{
OBITUARIES
}

\section{Mr. R. C. Mossman}

$\mathrm{T}$ HE death of Robert Cockburn Mossman at Buenos Aires on July 19 removes a natural genius whose scientific instincts found their full expression without the help of a formal scientific training.

Mossman was born in Edinburgh on November 7, 1870, was educated at the Royal High School and entered his father's business, for which he had neither liking nor aptitude. I met him first when he was a boy spending every penny he could get in equipping a second-order meteorological station in his father's garden, and he kept up continuous records there from 1886 until 1900. Dr. Alexander Buchan was quick to recognize Mossman's gifts and encouraged him to make the most of them. One of his earliest labours was an elaborate study of the climate of Edinburgh, which was followed later by a still fuller treatment of the climate of London. He frequently assisted at the Ben Nevis Observatory, often acting as temporary superintendent, and he earried out a series of comparative observations in a hut high up in Glen Nevis, where he lived alone for a year in 1901-1902. He was elected a fellow of the Royal Society of Edinburgh almost as soon as he came of age.

He joined the Scottish Antarctic Expedition under Dr. W. S. Bruce in 1902, taking charge of the meteorological and oceanographical work on the first cruise in the Weddell Sea. While wintering in 1903 at Laurie Island in the South Orkneys, Mossman set up a meteorological observatory on shore, and rather than break the continuity of the record he remained while the Scotia made her second trip to the Weddell Sea and so passed a second winter in great discomfort in the miserable climate he was determined to study. Thanks to his representations, the Argentine Government took over the observatory as a going concern, and Mossman paid a visit to Grahamland in the gunboat Uruguay to look for Charcot, who was then missing.

Short trips in whalers to Spitsbergen and the Greenland seas occupied the next two seasons and in the intervals he was joint author with two of his colleagues of "The Voyage of the Scotia".

Returning to Buenos Aires Mossman spent six years in the Argentine Meteorological Office while Mr. W. G. Davis was director. When my eyes broke down in $1913 \mathrm{I}$ was fortunate enough to have his help for a year in the editorship of "British Rainfall", and he remained in Great Britain until after the War.

Returning to the Argentine in 1920, Mossman filled several posts in the Argentine Meteorological Service in Buenos Aires and Cordova, being acting director in 1928-29 and receiving the appointment of head of the Climatological Department in 1930. $\mathrm{He}$ made a profound study of the climate of the southern continents and their relation to the Antarctic regions. The labours of an enthusiast for a life-time necessarily produced a flood of papers and memories. Including official reports, these could not number much less than a hundred.

In 1918 Mossman received the Keith Prize of the Royal Society of Edinburgh for his Antaretic work, and he also received the Gold Medal of the Royal Scottish Geographical Society. He did not concern himself with meteorological theory, but he had no superior in conscientious and tireless labour in the accumulation and orderly presentation of the observational facts on which all theory must be based. Hugh Robert Mrul.

\section{Mr. C. H. Turnor}

Mr. Christopher Hatton Turnor, whose death occurred on August 19 at the age of sixty-six, was well known for his active interest in the science and practice of agriculture. He was educated at Christ Church, Oxford, and then specialized in agriculture at the Royal Agricultural College, Cirencester, where he was one of a remarkable group of students that included also Lord Bledisloe; afterwards he proceeded to organize and develop the considerable estates he inherited from his uncle. Throughout his life he was indefatigable in studying the possibilities of using more seienee in agriculture, and his sound common sense and instinct for practicability helped him to select those methods most likely to be of value and to concentrate on them. Early in his career he became greatly impressed with the possibility of lucerne growing and he introduced this crop with great success into his system of farming. $\mathrm{He}$ also studied in detail the Danish methods of agriculture and engaged the services of an expert Danish farmer to run one of his farms on Danish lines so that he and other agriculturists might be able to see how far they embodied improvements likely to be useful in English conditions.

His interests were very wide and he was unusually well read. He travelled a good deal but never failed to keep his farmer's eyes open, and he invariably brought back a crop of new ideas and suggestions for the improvement of British agriculture by the introduction of some of the methods he had seen. His account of the Pontine Marshes is typical of his travel writings: vigorous and enthusiastic, and punctuated with many shrewd observations about the cultivators and their ways of doing things. His writings on English agriculture included "Land Problems and the National Welfare"; "Our Food Supply" and "The Land and the Empire", in all of which he urged the adoption of a more coherent plan of land utilization in which the landowner should play the part of organizer and leader, with the farmer and farm worker fitting into the scheme 
as producers. He had no use for the idle rich or for the man who simply extracted money or pleasure from his estate; his view was that the landowner had a definite place in English country life, with clear-cut duties and responsibilities for which he should train himself and on which he should act. His house was always open as a meeting place for those genuinely desirous to improve country life, and he and Mrs. Turnor were delightful and unforgettable hosts whose influence extended much farther than they realized. Few men strove more conscientiously to live up to their ideals than he did, and one can safely say that if more landowners had been animated by the same high purpose, and laboured with the same success as attended him, the history of British agriculture would have been very different.

E. J. RUSSELL.

\section{Dr. R. Hanitsch}

Dr. Richard Hanitsch died at Oxford on August 11 last. Born at Grossenstein, Germany, in 1860, he graduated Ph.D. in the University of Jena. During 1887-1895 he held the post of demonstrator in zoology in the University of Liverpool. During this period he took an active interest in marine biology and became an authority on the sponges, a group on which he wrote a number of papers and reports dealing with English, Irish and some of the foreign species. He also contributed, for a few years, the sections dealing with the literature on sponges and Protozoa to the Zoological Record, ending in about 1894. Dr. Hanitsch also contributed short papers on other zoological subjects including the pineal eye of Anguis and the structure of Limax. The two lastnamed were printed in the Liverpool Biological Society's Transactions.

From 1895 until 1919 he was director of the Raffles Museum at Singapore and during this period he became interested in Blattidæ. $\mathrm{He}$ contributed various papers on their systematics and continued the study of these creatures until about a year before his death. Dr. Hanitsch was also interested in numismatics and wrote several articles on this subject. In 1892 he married Miss Ethel Vernon of Liverpool and had five children. A. D. IMms.

Dr. R. Hanitsch came to Oxford after the War of 1914-18 and in the Hope Department of the University Museum continued his studies of Malaysian Blattidæ until failing health finally prevented further work in 1939. At the time of his death, papers on the Blattidæ of New Guinea, Federated Malay States, and Borneo were well advanced. He had written thirty-two papers on Blattidæ, mainly oriental, in which 17 new genera and 218 new species were described. As a result of this work, and the previous work of Mr. R. Shelford, the Hope Department became well known as a centre of study of these insects, of which many types are there preserved. The University awarded him an honorary M.A. in 1935. It is, perhaps, not widely known that in 1899 he conducted an expedition up Mt. Kina Balu in Borneo, though circumstances prevented him from reaching the summit : this resulted in the discovery of new species of reptiles, Amphibia, a new genus of fresh-water fish, many new insects and a new crustacean.

G. D. Hale Carpenter.

\section{Prof. N. T. M. Wilsmore}

IT is with great regret that his many friends in Great Britain have learned of the death in June of this year of Prof. N. T. M. Wilsmore.

Prof. Wilsmore was a graduate in chemistry of the University of Melbourne. Although he began his career as a student of engineering, he had to give up engineering science owing to short-sightedness. As a young man, Wilsmore went to University College, London, and worked in the laboratory of Sir William Ramsay, where he carried out many interesting and important researches, amongst which may be mentioned the discovery of ketene. After working some time in London, he went for a considerable period to Germany, where he gained an international reputation for his valuable work-in connexion especially with the determination of normal electrode potentials. Returning to University College about 1904, he became assistant professor of chemistry and greatly developed teaching and research in physical chemistry in the laboratory of Sir William Ramsay.

In 1913 Prof. Wilsmore was appointed professor of chemistry in the University of Western Australia at Perth. Here he built up an important school of chemistry, although he had to contend for many years with very inefficient laboratory accommodation. During the War of 1914-18, he did important war work in Australia and also came to London, where his services in the Department of Explosives Supply under Lord Moulton and Mr. Quinan were extremely valuable.

It may well be said that in Australia Wilsmore, like D. Steele, carried on the great tradition of Sir Orme Masson, and contributed very much to the development of chemical teaching and research in his native country. Wilsmore was specially interested in physical chemistry, and was indeed one of the principal exponents of that science as it was developed by the famous schools of Arrhenius, van't Hoff, Ostwald and Nernst. He was a man of extremely modest and retiring disposition, of great experimental ability combined with vast and accurate scholarship, and much beloved by all his students and colleagues. Towards the end of his life he acted for a while as deputy vicechancellor of the University at Perth. Owing to the age limit, he retired in 1937 . F. G. DonNan.

WE regret to announce the following deaths :

Prof. E. W. W. Carlier, emeritus professor of physiology in the University of Birmingham, on September 2, aged seventy-eight.

Mr. E. M. Kindle, formerly chief palæontologist of the Dominion Geological Survey (Canada), on August 29, aged seventy-two. 